\title{
Análisis clínico, radiológico e histológico de los fibromas cemento-osificantes de los maxilares*
}

\author{
Clinical, radiological and histological analysis of the cemento-ossifying \\ fibromas of the maxilla
}

\author{
L. Domínguez Cuadrado', R. Martín-Granizo López²
}

Resumen: Introducción. El fibroma cemento-osificante (FCO) en una neoplasia fibro-ósea benigna, de estirpe no odontogénica, más frecuente en mujeres entre la $3^{a}$ y $4^{a}$ décadas de la vida y que se localiza preferentemente en la región molar o premolar mandibular.

Objetivos. Analizar las características clínicas, radiológicas e histológicas del fibroma cemento-osificante (FCO) y su controvertida clasificación. Evaluar las lesiones fibro-óseas con las que es necesario realizar un diagnóstico diferencial para llevar a cabo un tratamiento adecuado.

Material y método. Se ha realizado un estudio retrospectivo durante el periodo de 1999-2002 de 10 pacientes con FCO, valorando la edad, sexo, antecedentes personales, sintomatología, localización y características radiográficas e histológicas de la lesión. En todos los pacientes se realizó una extirpación local del tumor y un seguimiento mínimo de seis meses tras la cirugía con controles clínicos y radiográficos.

Resultados. De los pacientes estudiados 7 eran mujeres y 3 varones, con edades comprendidas entre los 26 y 70 años. En la mayoría de los casos la lesión estaba localizada en el sector posterior mandibular y era asintomática. En la exploración física el hallazgo más frecuente fue un abombamiento de la cortical ósea. Radiológicamente se evidenciaba un patron mixto (radiolúcido-radiopaco) que en el análisis histológico correspondía a un estroma fibroso con depósitos calcificados trabeculares y/o esferoidales que recordaban respectivamente al hueso y/o cemento. El tratamiento definitivo consistió en la extirpación local de la lesión y curetaje, sin observarse ninguna recidiva durante el periodo de seguimiento.

Conclusión. El FCO suele ser una lesión asintomática que radiográficamente se presenta como una lesión delimitada, de patrón mixto (radiolúcidoradiopaco), que no afecta a los ápices dentarios. Debe realizarse un diagnóstico diferencial con otras lesiones fibro-óseas basado en la clínica, la histológía y el análisis radiográfico. Su tratamiento es conservador, siendo raras las recidivas.

Palabras clave: Fibroma cemento-osificante; Fibroma cementificante; Tumor no-odontogénico; Tumor maxilar; Patrón mixto.

1 Médico Residente

2 Médico Adjunto

Servicio de Cirugía Oral y Maxilofacial (Jefe de Servicio: Dr. A. Berguer) Hospital

Clínico San Carlos. Madrid, España.

Correspondencia:

Dr. Rafael Martín-Granizo López

Servicio de Cirugía Oral y Maxilofacial. Hospital Clínico San Carlos

C/ Profesor Martín Lagos s/n. 28040 Madrid, España.

e-mail: rmartin.hcsc@salud.madrid.org.

*Premio de la SECOM, Dr. Gómez Iglesias del año 2003.
Abstract: Introduction. The COF is a benign fibro-osseous neoplasm, more frequent in females on their $3^{\text {rd }}$ and $4^{\text {th }}$ decades of life, of nonodontogenic origin, that is preferentially localised on the molar and premolar mandibular area.

Objective. The objective of this study is to analyse the clinical, radiographic and histologic features of cemento-ossifying fibromas (COF) and its controversial classification. To evaluate the fibroosseous lesions from which a differential diagnosis is mandatory for a proper treatment.

Patients and method. A retrospective clinical study has been made from year 1999 to year 2000 of 10 patients with COF, analysing the age, sex, personal antecedents, symptoms, localisation and radiographic and histologic characteristics of such lesions. In all the patients a local excision of the tumour was performed, as well as a minimum follow-up of six months after surgery, using radiologic controls.

Results. Of all the patients studied, 7 were females and 3 males, with an age between 26 and 70 year-old. In the majority of the cases the lesion was placed in the posterior mandibular segment and was asymptomatic. On clinical examination the most common finding was a swelling of the bony cortex. Radiologically there was a mixed patron (radiolucid-radiopaque) which corresponded in the histologic analysis to a fibrous stroma with calcified trabecular and spherical deposits resembling to bone and cementum. Definite treatment included a local excision of the lesion followed by a simple curettage of the wound, with no evidence of recurrence during the follow-up.

Conclusions. The COF is a benign fibro-osseous neoplasm, of nonodontogenic origin, that is preferentially localised on the molar and premolar mandibular area. It uses to be asymptomatic and radiographically it shows as a well defined lesion, with a mixed patron, without apical involvement. A differential diagnosis must be made with other fibro-osseous lesions, based on the exploration, histology, and radiologic study. Its treatment must be conservative, being the recurrences very uncommon.

Key words: Cemento-ossifying fibroma; Cementifying fibroma; Non odontogenic tumour; Maxillary tumour; Mixed patron. 


\section{Introducción}

Los huesos maxilares tienen unas peculiares características que les hacen propicios para el asiento de una gran variedad de lesiones. Son huesos de osificación membranosa (con tejido óseo compacto y esponjoso similar al del resto del esqueleto), poseen dientes y en consecuencia, los restos de tejidos embrionarios a partir de los que se forman. Están revestidos por una mucosa gingival y pueden contener restos heterotópicos de tejido glandular salivar. Todo esto hace que en esta localización podamos encontrar quistes, tumores odontogénicos, tumores no odontogénicos y lesiones pseudotumorales.

Los tumores osteofibrosos de cabeza y cuello, fueron descritos por primera vez como en tidades patológicas por Lichtenstein hace más de 60 años. ${ }^{1,2}$

El fibroma cemento-osificante (FCO) es una neoplasia fibro-ósea de origen mesodérmico que se origina a partir de células multipotenciales del ligamento periodontal y forma parte de estas lesiones, aunque

\section{Introduction}

Maxillary bones have some special characteristics that make them favorable to suffer a large variety of lesions. They are membraneous ossification bones (with compact and spongy bone tissue similar to the rest of the skeleton), they have teeth and thus the rest of the embryonic tissues that they are formed from. They are lined by the gingival mucosa and may contain heterotropic remains of salivary glandular tissue. All this leads to the fact that we can find cysts, odontogenic tumors, non-odontogenic tumors and pseudotumoral lesions in this location. The osteofibrous tumors of the head and neck were first described as pathologic entities by Lichtenstein more than 60 years ago., 2

The cemento-ossifying fibroma (COF) is a fibro-osseous neoplasm having a mesodermic origin that originated from multipotential cells of the peridontal ligament and form a

Tabla 1. Presentación de casos clínicos de FCO.

\begin{tabular}{|c|c|c|c|c|c|}
\hline Edad y sexo & Localización & Dolor & Clínica & Radiología & Histología \\
\hline $39 \mathrm{~F}$ & Mandíbula, zona molar & No & Abombamiento cortical & $\begin{array}{l}\text { Área redondeada } \\
\text { radiolúcida con bordes } \\
\text { escleróticos } 15 \mathrm{~mm}\end{array}$ & $\begin{array}{l}\text { Estroma fibroso con } \\
\text { focos calcificados } \\
\text { trabeculares }\end{array}$ \\
\hline $56 \mathrm{~F}$ & $\begin{array}{l}\text { Encía insertada de área } \\
\text { molar mandibular }\end{array}$ & Sí & Masa pediculada & No & $\begin{array}{c}\text { Estroma fibroso con } \\
\text { focos calcificados } \\
\text { trabeculares y esferoidales }\end{array}$ \\
\hline $32 \mathrm{M}^{1}$ & $\begin{array}{l}\text { Encía insertada de } \\
\text { área molar mandibular }\end{array}$ & Sí & $\begin{array}{l}\text { Masa excrecente y } \\
\text { abombamiento } \\
\text { cortical }\end{array}$ & $\begin{array}{c}\text { Área radilolúcida } \\
\text { delimitada con zonas } \\
\text { radiopacas } 30 \text { × } 30 \mathrm{~mm}\end{array}$ & $\begin{array}{c}\text { Estroma fibroso con } \\
\text { focos calcificados } \\
\text { trabeculares y esferoidales }\end{array}$ \\
\hline $70 \mathrm{M}$ & $\begin{array}{l}\text { Mandíbula, } \\
\text { zona premolar }\end{array}$ & No & No & $\begin{array}{l}\text { Área radiolúcida } \\
\text { delimitada con zonas } \\
\text { radiopacas } 10 \mathrm{~mm}\end{array}$ & $\begin{array}{l}\text { Estroma fibroso con } \\
\text { focos calcificados } \\
\text { trabeculares }\end{array}$ \\
\hline $33 \mathrm{~F}$ & $\begin{array}{l}\text { Mandíbula, } \\
\text { zona molar }\end{array}$ & No & $\begin{array}{l}\text { Abombamiento } \\
\text { cortical }\end{array}$ & $\begin{array}{l}\text { Área radiolúcida } \\
\text { delimitada con zonas } \\
\text { radiopacas } 15 \mathrm{~mm}\end{array}$ & $\begin{array}{c}\text { Estroma fibroso con } \\
\text { focos calcificados } \\
\text { trabeculares y esferoidales }\end{array}$ \\
\hline $43 F^{2}$ & Maxilar superior & No & $\begin{array}{l}\text { Abombamiento } \\
\text { cortical }\end{array}$ & $\begin{array}{c}\text { Área radiolúcida } \\
\text { delimitada con zonas } \\
\text { radiopacas } 20 \times 30 \mathrm{~mm}\end{array}$ & $\begin{array}{l}\text { Estroma fibroso con } \\
\text { focos calcificados } \\
\text { esferoidales }\end{array}$ \\
\hline $42 \mathrm{~F}^{3}$ & $\begin{array}{l}\text { Mandíbula, } \\
\text { zona molar }\end{array}$ & No & No & $\begin{array}{l}\text { Área radiolúcida } \\
\text { delimitada } 15 \mathrm{~mm}\end{array}$ & $\begin{array}{c}\text { Estroma fibroso con } \\
\text { focos calcificados } \\
\text { trabeculares y esferoidales }\end{array}$ \\
\hline $33 \mathrm{M}$ & $\begin{array}{l}\text { Mandíbula, } \\
\text { zona premolar }\end{array}$ & Sí & $\begin{array}{l}\text { Abombamiento } \\
\text { cortical }\end{array}$ & $\begin{array}{l}\text { Área radiolúcida } \\
\text { delimitada con zonas } \\
\text { radiopacas } 10 \times 15 \mathrm{~mm}\end{array}$ & $\begin{array}{c}\text { Estroma fibroso con } \\
\text { focos calcificados } \\
\text { trabeculares y esferoidales }\end{array}$ \\
\hline $46 \mathrm{~F}^{4}$ & $\begin{array}{l}\text { Mandíbula, } \\
\text { zona molar }\end{array}$ & No & No & $\begin{array}{l}\text { Área radiolúcida } \\
\text { delimitada con zonas } \\
\text { radiopacas } 10 \mathrm{~mm}\end{array}$ & $\begin{array}{c}\text { Estroma fibroso con } \\
\text { focos calcificados } \\
\text { trabeculares y esferoidales }\end{array}$ \\
\hline $26 \mathrm{~F}$ & $\begin{array}{l}\text { Mandíbula, } \\
\text { zona molar }\end{array}$ & No & No & $\begin{array}{l}\text { Área radiolúcida, } \\
\text { delimitada } 15 \mathrm{~mm}\end{array}$ & $\begin{array}{l}\text { Estroma fibroso con } \\
\text { focos calcificados } \\
\text { trabeculares }\end{array}$ \\
\hline
\end{tabular}


dadas sus características clínicas, radiológicas e histológicas su clasificación ha sido y es muy controvertida. ${ }^{3}$

El objetivo del presente trabajo es analizar las características clínicas, radiológicas e histológicas del FCO haciendo énfasis en la apariencia radiológica de sus diferentes fases de desarrollo, en su clasificación y en las distintas lesiones fibro-óseas con la que es necesario realizar un diagnóstico diferencial para llevar a cabo un tratamiento adecuado.

\section{Material y método}

Se ha realizado un estudio retrospectivo de los casos de FCO diagnosticados en nuestro Servicio durante el periodo de 1999-2002, teniendo en cuenta la edad, sexo, antecedentes y sintomatología de los pacientes, así como el estudio radiográfico e histológico de las lesiones (Tabla 1). Encontramos diez pacientes, siete mujeres y tres varones cuyas edades oscilaban entre los 26 y 70 años (Fig. 1). En tres part of these lesions. However, given their clinical, radiological and histological characteristics, their classification has been and is very controversial. ${ }^{3}$

The objective of this present study is to analyze the clinical, radiological and histological characteristics of the COF, stressing the radiological appearance of its different development phases, its classification and the different fibroosseous lesions, so a differential diagnosis must be performed to carry out an adequate treatment.

\section{Material and method}

A retrospective study was performed of the COF cases diagnosed in our Service during the period of 1999-2002, considering age, gender, background and symptoms of the patients as well as the radiographic and histologic study of the lesions (Table 1). We found ten patients, seven women

Table 1. Presentation of COF clinical cases

\begin{tabular}{|c|c|c|c|}
\hline Age and gender & Location & Pain & Symptoms \\
\hline $39 \mathrm{~F}$ & Mandible, molar area & No & Cortical insuflation \\
\hline $56 \mathrm{~F}$ & $\begin{array}{l}\text { Gum inserted in } \\
\text { mandibular molar area }\end{array}$ & Yes & Pediclated mass \\
\hline $32 \mathrm{M}^{1}$ & $\begin{array}{l}\text { Gum inserted in } \\
\text { mandibular molar area }\end{array}$ & Yes & $\begin{array}{l}\text { Excrescent mass an } \\
\text { cortical insuflation }\end{array}$ \\
\hline $70 \mathrm{M}$ & $\begin{array}{l}\text { Mandible, } \\
\text { premolar area }\end{array}$ & No & No \\
\hline $33 \mathrm{~F}$ & $\begin{array}{l}\text { Mandible, } \\
\text { molar area }\end{array}$ & No & $\begin{array}{l}\text { Cortical } \\
\text { insuflation }\end{array}$ \\
\hline $43 F^{2}$ & Upper maxilla & No & $\begin{array}{l}\text { Cortical } \\
\text { insuflation }\end{array}$ \\
\hline $42 F^{3}$ & $\begin{array}{l}\text { Mandible, } \\
\text { molar area }\end{array}$ & No & No \\
\hline $33 \mathrm{M}$ & $\begin{array}{l}\text { Mandible, } \\
\text { premolar area }\end{array}$ & Yes & $\begin{array}{l}\text { Cortical } \\
\text { insuflation }\end{array}$ \\
\hline $46 F^{4}$ & $\begin{array}{l}\text { Mandible, } \\
\text { molar area }\end{array}$ & No & No \\
\hline $26 \mathrm{~F}$ & $\begin{array}{l}\text { Mandible, } \\
\text { molar area }\end{array}$ & No & No \\
\hline
\end{tabular}

\section{Radiology}

Surrounded radiolucent area with sclerotic borders $15 \mathrm{~mm}$

No

Defined radiolucent area with radiopaque areas $30 \times 30 \mathrm{~mm}$

Defined radiolucent area with radiopaque areas $10 \mathrm{~mm}$

Defined radiolucent area with radiopaque areas $15 \mathrm{~mm}$

Defined radiolucent area with radiopaque areas $20 \times 30 \mathrm{~mm}$

Defined radiolucent area $15 \mathrm{~mm}$

Defined radiolucent area with radiopaque area $10 \times 15 \mathrm{~mm}$

Defined radiolucent area with radiopaque areas $10 \mathrm{~mm}$

Defined radiolucent area $15 \mathrm{~mm}$

\section{Histology}

Fibrous stroma with trabecular calcified foci

Fibrous stroma with calcified trabecular and spherical foci

Fibrous stroma with calcified trabecular and spherical foci

Fibrous stroma with calcified trabecular foci

Fibrous stoma with calcified trabecular and spherical stroma

Fibrous stoma
with calcified
spherical foci

Fibrous stroma with calcified trabecular tand spherical foci

Fibrous stroma with calcified trabecular and spherical foci

Fibrous stroma with calcified trabecular and spherical foci

Fibrous stroma with calcified trabecular foci 
de los pacientes existía una enfermedad periodontal subyacente, en otros dos un antecedente traumático previo (exodoncia de un cordal y de un molar un año antes y dos meses antes del diagnóstico de la lesión, respectivamente) y en una de las mujeres un ameloblastoma extirpado 7 años antes. En todos los pacientes se realizó una OPG y una TC en aquellos en los que existía una lesión intraósea mayor de $10 \mathrm{~mm}$ (6 casos). Todas las lesiones, excepto una localizada en maxilar superior, asentaban en la mandíbula, concretamente en el área molar y premolar de la misma (Figs. 2 y 3).

Se realizó una biopsia excisional en ocho de los pacientes, extirpando la lesión y cureteando la cavidad residual. Solamente en los pacientes que presentaban una tumoración excrecente mucosa, se llevó a cabo una biopsia incisional y posteriormente un tratamiento definitivo con extirpación completa de la lesión. El tratamiento quirúrgico se realizó bajo anestesia general en 7 pacientes (debido a la extensión y localización de la lesión) y con anestesia local en los tres restantes. La cavidad residual no se rellenó con material alguno en ninguno de los casos.

\section{Resultados}

Macroscópicamente los tumores resecados tenían un aspecto lobulado, de consistencia dura a la palpación. En el análisis histológico se observó un estroma de tejido conectivo fibroso con canales vasculares, trabéculas óseas y/o pequeños focos esféricos calcificados coalescentes. No se evidenciaron mitosis ni atipias celulares (Fig. 4).

Se realizó un seguimiento mínimo de 6 meses en todos los pacientes, con OPG de control en el 1, 3 y 6 mes postcirugía. No se detectó ninguna recidiva y se objetivó una adecuada osificación de los defectos óseos residuales en los 10 pacientes (Figs. 5-8).

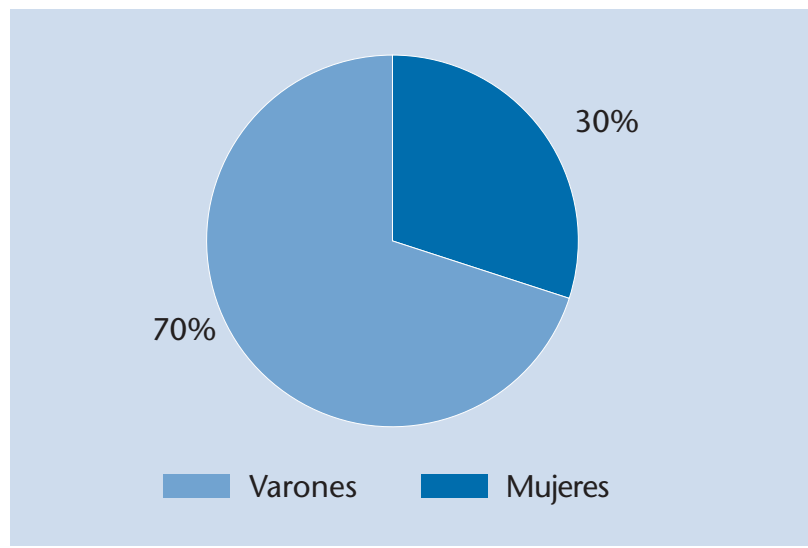

Figura 1. Distribución por sexo. Figure 1. Distribution by gender. (Males, Females).

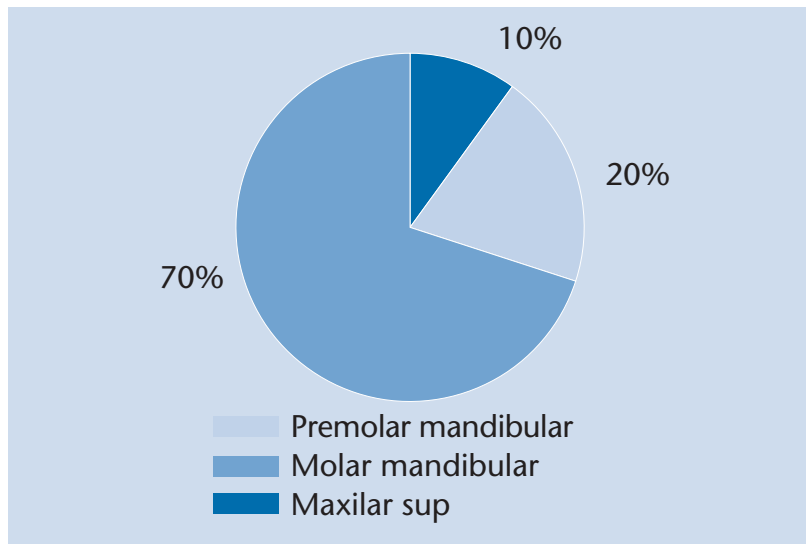

Figura 2. Distribución por localización de la lesión. Figure 2. Distribution by lesion site. (Mandibular premolar, Mandibular molar, Upper maxilla).

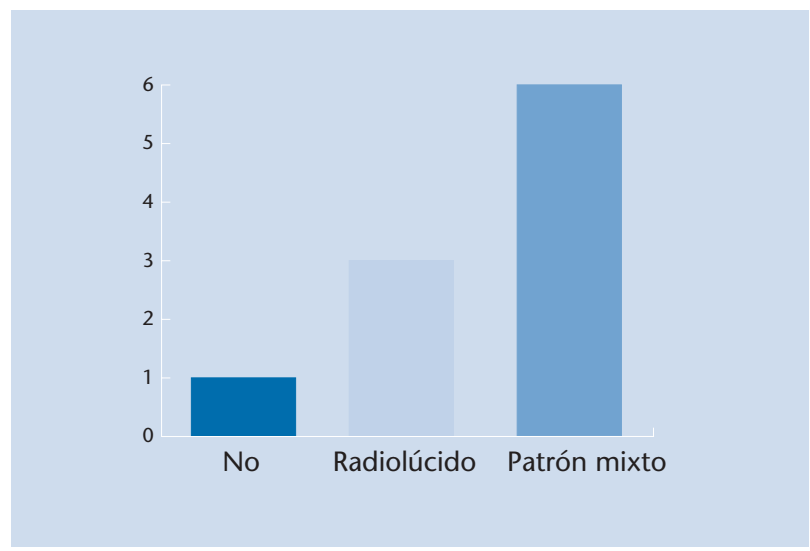

Figura 3. Aspecto radiológico.

Figure 3. Radiological appearance. (No, Radiolucent, Mixed pattern). and three men whose ages ranged from 26 to 70 years (Fig. 1).

In three of the patients, there was underlying periodontal disease, two others had a previous traumatic background (exodontia of a third molar and of a molar one year before and two months before the diagnosis of the lesion, respectively) and an ameloblastoma extracted 7 years before in one of the women. In all the patients an OPG was performed and a CT was done in those in whom there was an intraosseous lesion greater than $10 \mathrm{~mm}$ (6 cases).

All the lesions, except one located in the upper maxilla, were found in the mandible, specifically in its molar and premolar area (Fig. 2 and 3).

An excisional biopsy was performed in eight of the patients, excising the lesion and performing a curretage of the residual cavity. An incisional biopsy and then a final treatment with complete extraction of the lesion were carried out only in patients who presented a verrucous tumor of the mucosa. The surgical treatment was performed under general anesthesia in 7 patients (due to the extension and location of the lesion) and with local anesthesia in the remaining three. The residual cavity was not filled with any material in any other cases.

\section{Discusión}

Desde 1972 y tras la modificación realizada por Schajowicz, ${ }^{4}$ la OMS consideraba al fibroma cementante y al fibroma osificante como entidades distintas, perteneciendo el primero al grupo de los tumores de

\section{Results}

Macroscopically, the resected tumors had a lobulated appearance, with a hard consistency on palpation. In the histological analysis, a stroma of the fibrous connective tis- 
estirpe odontogénica y el segundo a los tumores de estirpe no odontogénica. Únicamente un adecuado análisis histológico permitía la diferenciación de ambas patologías, considerándose un fibroma cementante si se hallaban depósitos de cemento en el estroma fibroso. En 1992 la OMS modificó la clasificación de las lesiones maxilares, englobando bajo la denominación de FCO al fibroma cementante y al fibroma osificante e incluyéndolo dentro del grupo de los tumores de estirpe no odontogénica. ${ }^{5,6}$ Sin embargo, esta terminología y nueva clasificación no es universalmente aceptada, ya que se ignora la aparición de depósitos de cemento en lesiones fibro-óseas de otras partes del cuerpo.

El presente trabajo va a basarse en esta última clasificación de 1992, definiendo por lo tanto al FCO como una neoplasia benigna, osteogénica (no odontogénica), bien delimitada y raramente encapsulada, consistente en tejido fibroso con cantidades variables de material mineralizado similar al hueso y/o cemento.

Es una lesión fibro-ósea relativamente rara y según Eversole y cols, ${ }^{7}$ típicamente afecta a mujeres $(5: 1)$ entre la $3^{\mathrm{a}}$ y $4^{\mathrm{a}}$ décadas de la vida, con una predilección por el área molar (52\%) y premolar (25\%) del maxilar inferior, como ocurre en 9 de los casos estudiados. Aunque el maxilar, el cigoma e incluso etmoides, hueso frontal y región petromastoidea pueden también ser afectados por esta lesión, de los casos analizados solamente en uno el FCO se localizaba en maxilar superior. Distintos autores coinciden en afirmar que los FCO de línea media facial y senos paranasales tienen un comportamiento más agresivo que los de localización mandibular.8, 9 Pese a que es una lesión intraósea, se han descrito casos afectando encía y tejidos blandos. ${ }^{10}$ En nuestro estudio, encontramos dos pacientes en los que la encía estaba afectada de forma evidente y se podía observar una lesión excrecente, ulcerada, dolorosa, friable y sangrante al tacto.

Clínicamente el FCO suele ser asintomático (detectándose casualmente con frecuencia), aunque en casos de larga evolución puede originar una asimetría facial creciente (generalmente indolora) por un abombamiento de la cortical ósea.

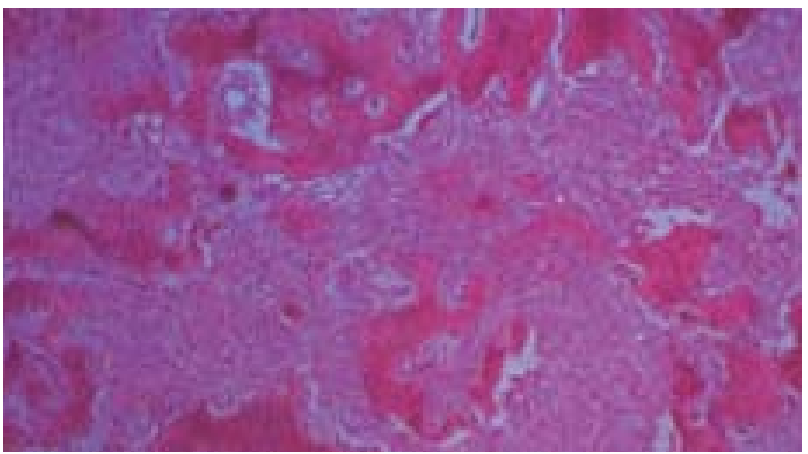

Figura 4. Imagen histológica de un FCO (HE x 20).

Figure 4. Histological image of a COF (HE $\times 20)$.
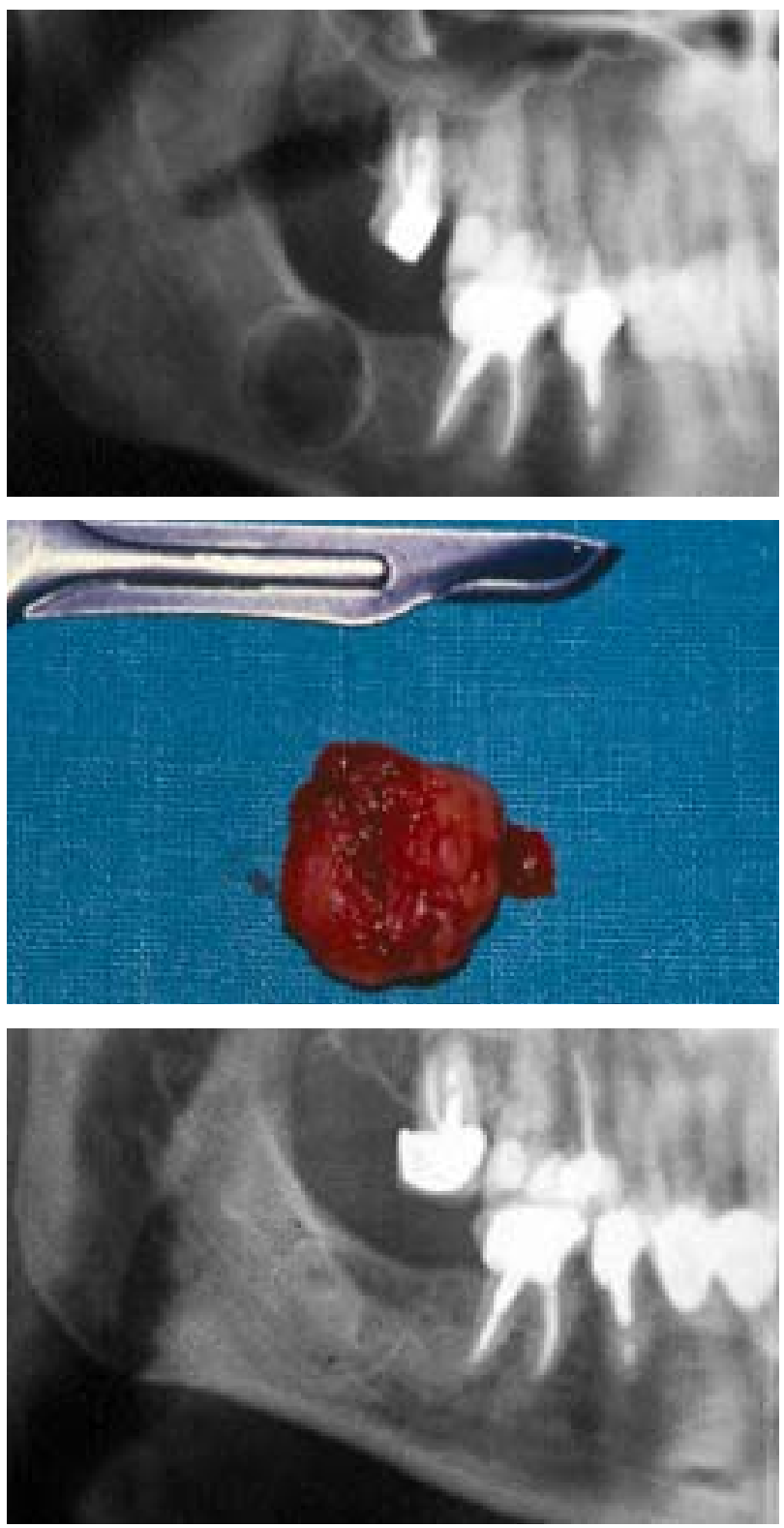

Figura 5. Caso clínico 1. a) Imagen radiolúcida de un FCO. b) Aspecto macroscópico del espécimen. c) Imagen radiológica 1 año postcirugía. Figure 5. Clinical Case 1. a) Radiolucent image of a COF. b) Gross appearance of the specimen. c) Radiological image 1 year post-surgery. sue with vascular canal, bone trabeculas and/or small coalescent calcified spherical foci was observed. No mitosis or cellular atypias were observed (Fig. 4).

A minimum follow-up of 6 months was performed in all the patients, with control OPG at, ${ }^{1,3}$ and 6 months post-surgery. No relapse was detected and adequate ossification of the residual bone defects was observed in the ten patients (Fig. 5, 6, 7 and 8).

\section{Discussion}

Since 1972 and after the modification performed by Schajowicz, 4 the WHO considered cementing fibroma and ossifying fibroma as different entities, the first belonging to the group of tumors of odontogenic lineage and the second to the tumors of non-odontogenic lineage. Only an adequate histologic analysis permits both pathologies to be differentiated, it being considered a cementing fibroma if cement deposits are found in the fibrous stoma. In 1992, the WHO modified the classification of the maxillary lesions, including cementing fibroma and ossifying fibroma under the COF denomination and including them within the group of nonodontogenic lineage tumors. 5,6 However, this terminology and new classification is not universally accepted, since it ignores the appearance of cement deposits in the fibro-osseous lesions of other parts of the body.

The present study is going to be based on this last classification of 1992, 
La apariencia radiológica de esta lesión es muy variable, aparentemente dependiendo de la etapa de su desarrollo. En ocasiones se detecta un área radiolúcida uni o multilocular bien delimitada y en otros casos una zona radiolúcida también circunscrita con distintos grados de radiopacidad en su interior. Para algunos autores, esta lesión está rodeada de una cápsula fibrosa, siendo este un aspecto muy importante para el diagnóstico diferencial con la displasia fibrosa. ${ }^{11}$ Otros autores sin embargo, admiten que es una lesión circunscrita, con un halo radiolúcido claro, pero que no corresponde de ninguna manera a una cápsula sino a una transición entre tejido displásico y hueso sano. ${ }^{12}$ También se ha especulado sobre el origen de las distintas radiodensidades de su interior, señalando algunos que se trata de un proceso madurativo según el cual, cuanto más antigua sea la lesión mayores zonas radiopacas presentará. ${ }^{13}$ Según nuestra experiencia, las lesiones de menor tamaño y por tanto de menor tiempo de evolución, apenas presentaban radiopacidades en su interior y los FCO más grandes tenían un patrón mixto predominantemente radiopaco, lo que apoyaría esta teoría. Es rara la reabsorción o desplazamiento de las raíces dentales adyacentes, pero puede aparecer en lesiones de gran tamaño o de larga evolución.

No tiene un factor etiológico claro, pero se ha relacionado con procesos inflamatorios (periodontitis), exodoncias y antecedentes traumáticos. ${ }^{14,15}$ En los pacientes examinados, la enfermedad periodontal aparece como antecedente en tres ocasiones y la exodoncia de un tercer molar en otra. La paciente que fue intervenida años antes de un ameloblastoma, presentaba el FCO en el lado opuesto de la mandíbula, por lo que no lo consideramos un factor predisponerte.

En el estudio histológico, se observa un estroma fibroso constituido por células fusiformes que se entremezclan con focos calcificados trabeculares y/o esferoidales que recuerdan respectivamente al hueso y al cemento. Tiene una vascularización moderada (con extravasación eritrocitaria ocasional), es rara la actividad mitótica o atipias, pueden encontrarse células gigantes (generalmente situadas en el centro del estro$\mathrm{ma})^{16,17}$ y en algunas zonas aparece un infiltrado inflamatorio agudo con múltiples polimorfonucleares. El FCO presenta un creci-
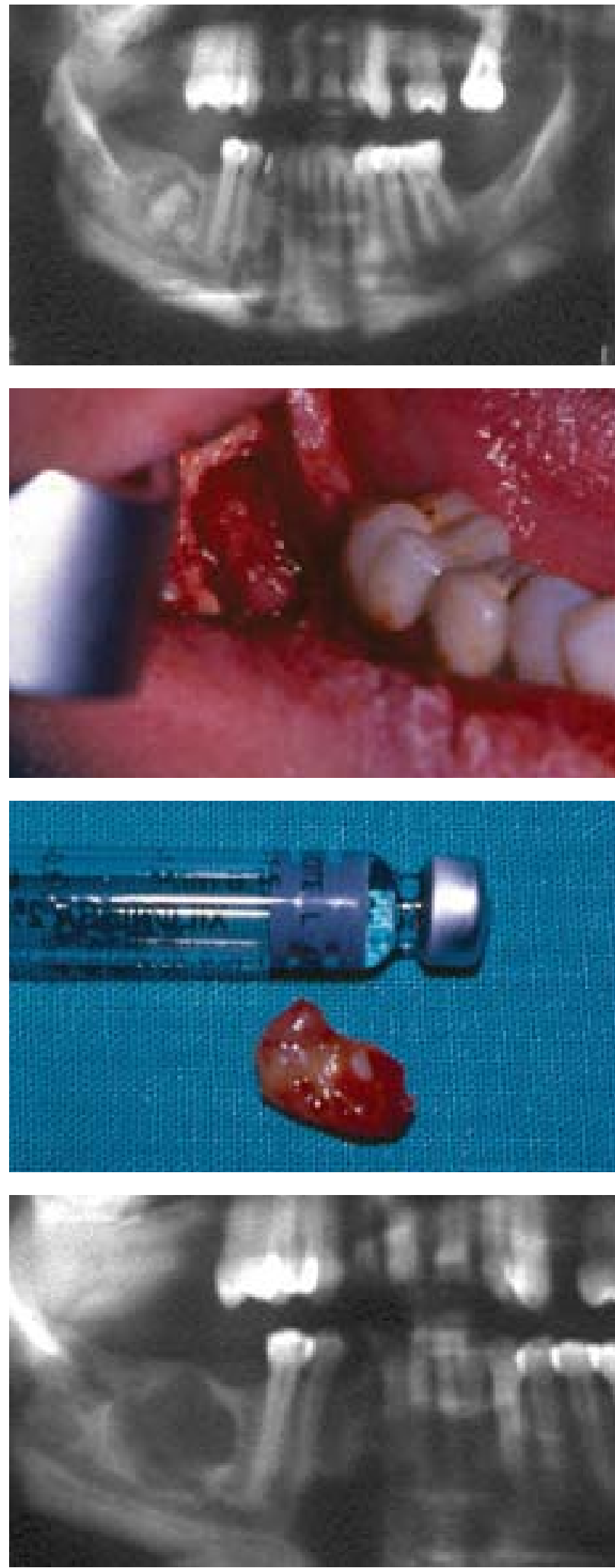

Figura 6. Caso clínico 2. a) Patrón radiológico mixto. b) Lecho quirúrgico. c) Aspecto macroscópico del espécimen. d) Imagen radiológica a los 2 meses de la cirugía.

Figure 6. Clinical Case 2. a) Mixed radiological pattern. b) Surgical bed. c) Gross appearance of the specimen. d) Radiological image at 2 months of surgery. thus defining the COF as a benign neoplasm that is osteogenic (non-odontogenic), well defined and rarely encapsulated, consisting of fibrous tissue with variable amounts of mineralized material similar to bone and/or cement.

It is a fibro-osseous lesion that is relatively rare and, according to Eversole et al., ${ }^{7}$ that typically affects women (5:1) between the $3 r d$ and 4th decades of life, with a predilection for the molar (52\%) and premolar (25\%) area of the inferior maxilla, as occurs in 9 of the cases studied. Although the maxilla, zygoma, and even ethmoids, frontal bone and petromastoid region may also be affected by this lesion, the COF was located in the upper maxilla in only one of the cases analyzed. Different authors coincide in stating that the COF of the middle facial line and paranasal sinuses have a more aggressive behavior than those having a mandibular location.8, 9 In spite of the fact that it is an intraosseous lesion, cases affecting the gum and soft tissues have been described.10 In our study, we have found two patients in whom the gum was clearly affected and an excres cent, ulcerated, painful, friable lesion that bled when touched could be observed.

Clinically, COF is generally asymptomatic (being frequently detect- 

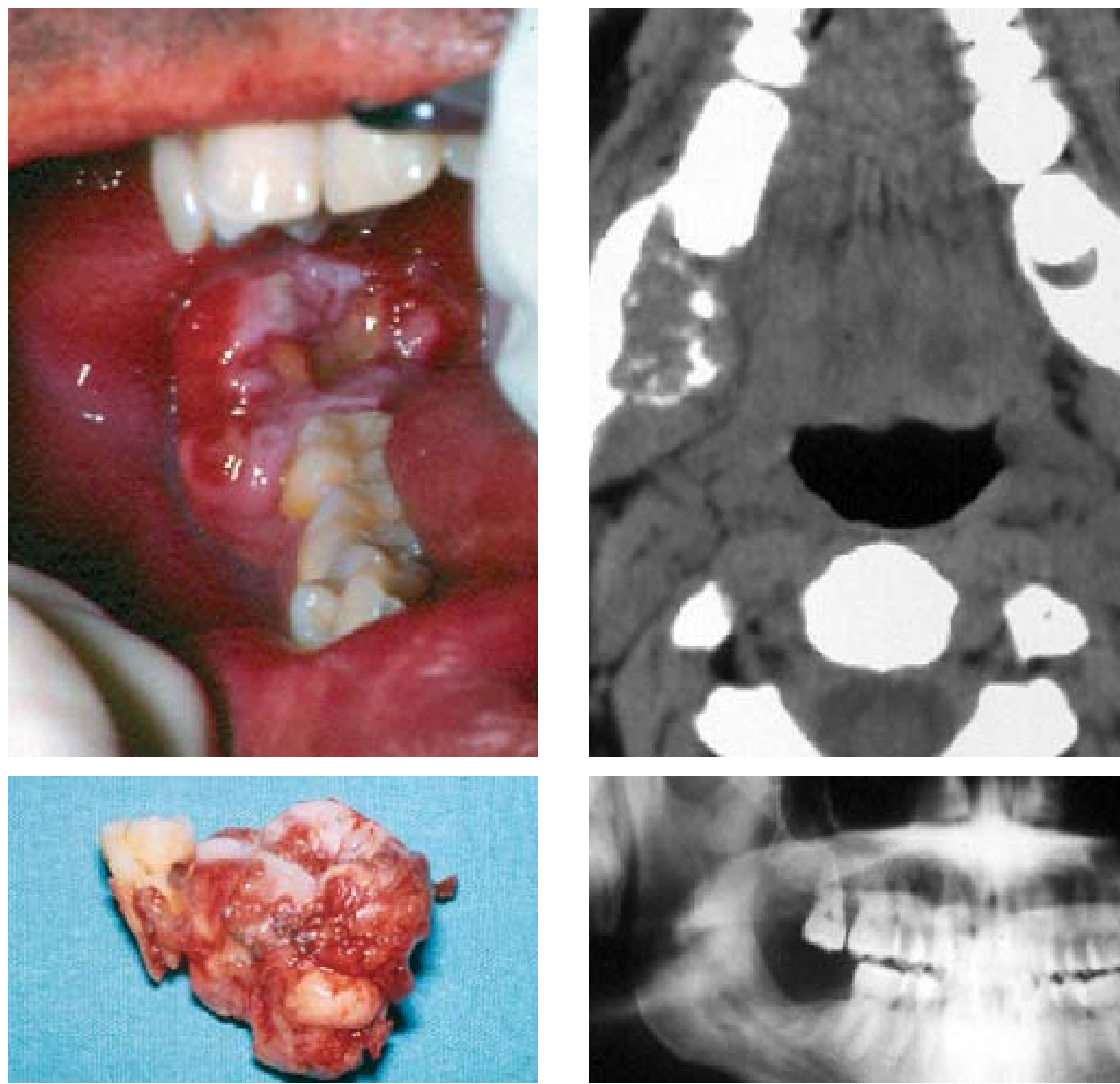

Figura 7. Caso clínico 3. a) Lesión excrecente y ulcerada biopsiada e informada como FCO. b) Imagen radiológica (TC). c) Espécimen quirúrgico. d) Imagen radiológica 1 año postcirugía.

Figure 7. Clinical Case 3. a) Excrescent and ulcerated lesion that is biopsied and informed as COF. b) Radiological image (CT). c) Surgical specimen. d) Radiological image 1 year post-surgery.

miento lento pero constante, por lo que es necesaria su extirpación. Para algunos, la cantidad de cemento existente en el FCO está directamente relacionado con un comportamiento más agresivo del mismo. ${ }^{13}$ En los casos que hemos detectado en nuestro estudio se confirma este hecho, los FCO más grandes y de comportamiento más agresivo presentaban una mayor cantidad de cemento en su estroma. Generalmente, y nuestra experiencia así lo demuestra, basta con un tratamiento conservador enucleando la lesión, siendo muy raras las recidivas. ed casually), although in long evolution cases, a growing facial asymmetry (generally unpainful) can be caused due to bone cortical curvature.

The radiological appearance of this lesion varies greatly, apparently depending on the stage of its development. On occasions, a well defined uni- or multilocular radiolucent area and in other cases, a radiolucent area that is also circumscribed with different grades of radiopacity inside are detected. For some authors, this lesion is surrounded by a 
Es necesario por lo tanto una minuciosa historia clínica y exploración, un análisis radiológico detallado y sobre todo un examen anatomo-patológico correcto encaminados a realizar un adecuado diagnóstico diferencial. ${ }^{16,17}$ Las lesiones fibro-óseas a descartar para llevar a cabo el diagnóstico de fibroma cemento-osificante son: ${ }^{18}$

Displasia fibrosa. Es una lesión fibroósea benigna y progresiva en la que el tejido óseo normal es sustituido por tejido fibroso con áreas fasciculadas o francamente óseas. Puede ser mono o poliostótica según afecte a uno o varios huesos. En la forma poliostótica existen alteraciones cutáneas y/o endocrinas. La displasia de los maxilares es casi siempre de tipo monostótico. Es más frecuente en mujeres y en los maxilares suele producir una asimetría por expansión del hueso alveolar indolora. Radiológicamente se observa una lesión de patrón mixto (radiolúcida-radiopaca) y mal delimitada lo que constituye el principal signo radiológico para el diagnóstico diferencial con el FCO.

Displasia cemento-ósea focal (Fig. 9). $\mathrm{Al}$ igual que el FCO es más frecuente en mujeres, en maxilar inferior y asintomática. En la exploración radiológica se evidencia una zona radiopaca (sin alternar con áreas radiolúcidas) de bordes bien definidos, que puede estar conectada con el ápice dental. En el estudio anatomopatológico aparece un tejido fibroso con mínima infiltración linfocítica y masas de cemento, tejido pseudo-osteoide y trama ósea.

FCO Juvenil. Contrariamente al FCO suele aparecer en pacientes menores de 15 años, predominando en maxilar superior y con un crecimiento rápido que frecuentemente erosiona los tejidos óseos circundantes. El cuadro histológico se caracteriza por un estroma célulo-vascular con cantidad variable de células gigantes, escaso colágeno y pequeños osículos rodeados de un halo osteoide.

Osteoma osteoide. Es más frecuente en personas menores de 30 años y en varones, excepcional en los maxilares (asienta típicamente en fémur, tibia o falanges). Ocasiona un dolor de predominio nocturno que es muy orientativo para su diagnóstico diferencial con otras lesiones óseas y en la RX aparece como un área radiolúcida bien circunscrita con halo esclerótico.

Osteoblastoma. Asienta preferentemente en la columna vertebral (rara vez en la mandíbula), ocasiona dolor y la imagen radiológica es muy variable pero generalmente mal definida (en el FCO la lesión típicamente está bien delimitada) y con erosión de la cortical ósea.

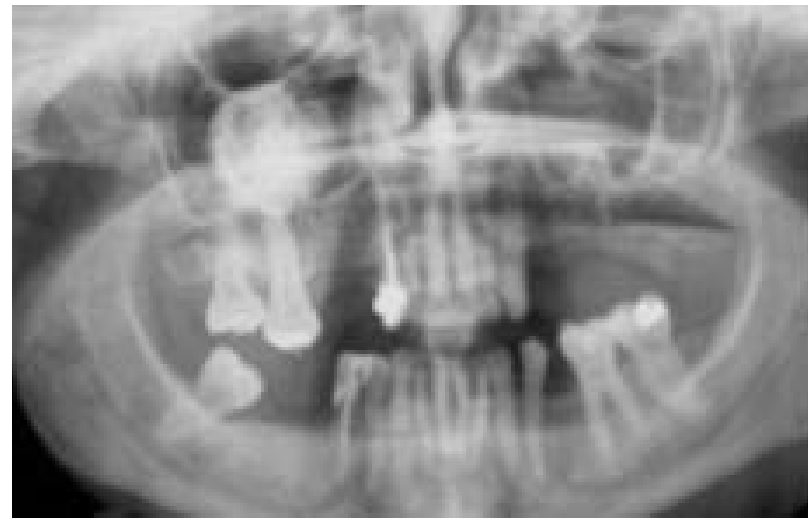

fibrous capsule, this appearance being very important for the differential diagnosis of fibrous dysplasia. ${ }^{11}$ Other authors, however, admit that it is a circumscribed lesion, with a clear radiolucent halo, but that it does not correspond in any way to a capsule but rather to a transition between dysplasic tissue and healthy bone. ${ }^{12}$ There has also been speculation on the origin of the different radiodensities of its inside, some stating that it is a madurative process according to which, the older the lesion, the greater the radiopaque areas presented. ${ }^{13}$ According to our experience, the smaller lesions and thus those having less evolution time, hardly presented radiopacities inside and the largest COF have a mixed pattern that is predominantly radiopaque, which would support this theory. Reabsorption or displacement of the adjacent dental roots is rare, but it can appear in large sized or long evolution lesions.

The etiologic factor is not clear, but it has been related with inflammatory processes (periodontitis), exodontias and traumatic backgrounds. ${ }^{14,15}$ In the patients examined, periodontal disease appears as
Fura 8. Caso clínico 4. a) y b) Lesión predominantemente radiopaca en Fure 8. Clinical Case 4. a) and b) Predominately radiopaque lesion in upper maxilla. c) Radiological image 3 months post-surgery a background on three occasions and exodontia of a third molar in another. The patient who was operated due to an ameloblastoma years earlier presented the COF on the opposite side of the mandible, so that we do not consider it a predisposing factor.

In the histological study, a fibrous stroma made up of fusiform cells that are mixed with calcified trabecular and/or spherical foci that resemble, respectively, bone and cementum, is observed. It has a moderate vascularization (with occasional erythrocytic extravasation), mitotic activities or atypias is rare, giant cells (generally located in the center of 
Cementoblastoma benigno. Más frecuente en menores de 20 años, localizado generalmente en región molar mandibular e íntimamente asociado con los ápices dentarios. El dolor y la expansión de la cortical ósea son síntomas y signos característicos.

Fibroodontoma ameloblastico. Afecta sobretodo a individuos jóvenes y la región del ángulo mandibular. En el análisis radiográfico se observa una lesión circunscrita rodeada de un halo esclerótico con un foco radiopaco. Histológicamente son tumoraciones lobuladas rodeadas de una cápsula fibrosa y formadas por tejido conectivo mixoide con cordones de epitelio odon-

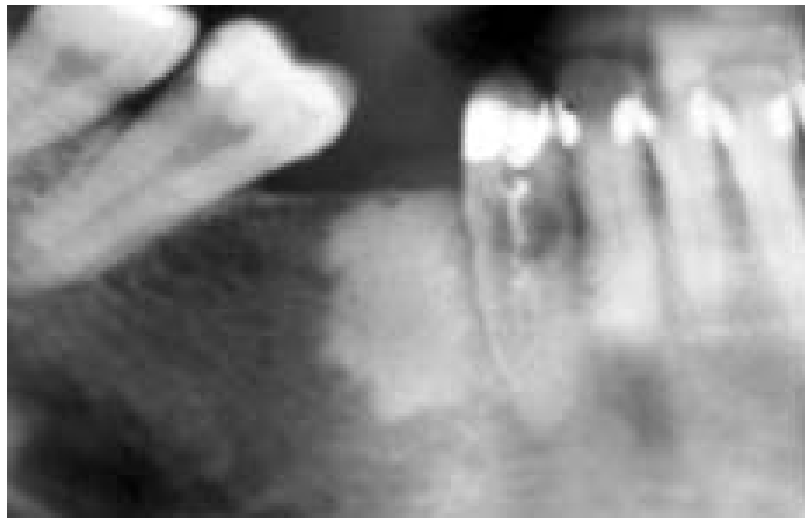

Figura 9. Displasia cemento-osificante focal. Figure 9. Focal cemento-ossifying dysplasia. the stroma) can be found ${ }^{16,17}$ and in some zones, there is an acute inflammatory infiltrate with multiple polymorphnuclears. COF has a slow but constant growth, so that it must be excised. For some, the amount of cementum existing in the COF is directly related with its more aggressive behavior. ${ }^{13}$ This fact has been confirmed in the cases that we have detected in our study; the larger COF with togénico que poseen células aún en proceso de diferenciación que producen dentina y esmalte.

Cementoblastoma. Aparece en le segunda y tercera década de la vida, más frecuentemente en la región posterior mandibular. Siempre se asocia a raíces dentales y con frecuencia provoca su reabsorción. Radiológicamente es una lesión opaca con un halo radiolúcido y el estudio histológico revela un conglomerado de material similar al cemento y tejido conectivo. Muchas de las trabéculas cementales están rodeadas por cementoblastos en actividad.

Osteomielitis. El dolor, la inflamación y la afectación del estado general orientan hacia un proceso inflamatorio de este tipo.

Osteosarcoma. Es un tumor óseo primario maligno y de rápida progresión que provoca dolor, trastornos sensitivos, limitación de la movilidad mandibular y desplazamiento o movilidad de las piezas dentarias. En la RX se evidencia con frecuencia rizólisis y afectación de la cortical ósea.

\section{Conclusiones}

El FCO es una entidad rara, de clasificación controvertida que actualmente se considera perteneciente a los tumores no odontogénicos. Afecta más frecuentemente a mujeres entre los 30 y 40 años y se localiza fundamentalmente en la región posterior de la mandíbula. Suele ser asintomático y tiene una apariencia radiológica variable, en función del tiempo de evolución y de la fase de desarrollo. Siempre es una lesión circunscrita y el patrón mixto (en el que se alternan áreas radiolúcidas con otras radiopacas) es característico de lesiones en etapas avanzadas. La histología demuestra un estroma conectivo fibroso con focos trabeculares y esferoidales coalescentes calcificados. Su comportamiento es benigno y basta con una extirpación local de la lesión.

\section{Agradecimientos}

A los anatomopatólogos, Dres. Luis Ortega (Madrid) y Conchita Alvarez-Cañas y Antonio González-Fernández Carreño (León) por su ayuda en el análisis histológico de los casos. more aggressive behavior presented a greater amount of cementum in their stroma. Generally, and as demonstrated by our experience, a conservative treatment, enucleating the lesion, is sufficient, relapses being very rare.

Thus, a careful clinical history and examination, detailed radiologic analysis and above all, correct pathology examination aimed at performing an adequate differential diagnosis are necessary. 16,17 The fibro-osseous lesions that must be ruled out to carry out the diagnosis of cemento-ossifying fibroma are: ${ }^{18}$

Fibrous dysplasia. It is a benign and progressive fibro-osseous lesion in which the normal bone tissue is substituted by fibrous tissues with fasciculated or frankly bone areas. It can be mono- or polyostotic according to whether it affects one or several bones. In the polyostotic form, there are cutaneous and/or endocrine alterations. The dysplasia of the maxillas is almost always monostotic. It is more frequent in women and asymmetry is generally produced in the maxillas due to expansion of the painless alveolar bone. Radiologically, a mixed pattern (radiolucent-radiopaque) and poorly defined lesion is observed, which constitutes the main radiological sign for the differential diagnosis with COF.

Focal cemento-osseous dysplasia (Fig. 9). As with the COF, it is more frequent in women, in the lower maxilla and is asymptomatic. In the radiological examination, a radiopaque zones is seen (that does not alternate with radiolucent areas), having well defined borders, that may be connected with the dental apex. The pathological study shows a fibrous tissue with minimum lymphocytic infiltration and masses of cementum, pseudo-osteoid tissue and bone damage.

Juvenile COF. Contrary to COF, it generally appears in patients under 15 years of age, predominating in the upper maxilla and with rapid growth that frequently erodes the surrounding bone tissues. The histological picture is characterized by a cellular-vascular stoma with variable amount of giant cells, scarce collagen and small ossicles surrounded by an osteoid halo.

Osteoid osteoma. It is more frequent in persons under 30 years of age and in males, rare in the maxilla (typically found 


\section{Bibliografía}

1. Lichtenstein I. Polyostotic fibrous dysplasia of bone. Arch Surg 1938;36:874-98.

2. Lichtenstein, Jaffe HL. Fibrous dysplasia of bone. Arch Pathol 1942;33:777-816.

3. Waldron CA. Bone Pathology. Neville BW, Damm DD, Allen CM, Bouquot JE. Oral Maxillofac Pathol. WB Saunders Co. Philadelphia 1995:443-92.

4. Schajowicz F. Tumores y lesiones pseudotumorales de huesos y articulaciones. Madrid. Panamericana 1982.

5. Waldrom CA. Fibro-osseous lesions of the jaws. J Oral Maxillofac Surg 1993;51:828-35.

6. De Vicente JC, González S, Santamaría J, Madrigal B. Non odontogenic tumours of the jaws: classification, behavoir and diagnosis. Med Oral 1997;2:83.

7. Eversole LR, Leider AS, Nelson K. Ossifying fibroma: a clinicopathologic study of 64 cases. Oral Surg Oral Med Oral Pathol 1985;60:505-11.

8. Cox VS, Rimmel FL, Marenttete LI, Ness JA. Ethmoidal cemento-ossifying fibroma: the transglabellar/ subcranial approach. Otolaryngol Head Neck Surg 1996; 114:335-8.

9. Saito K, Fukuta K, Takahashi M, y col. Benign fibroosseous lesions involving the skull base, paranasal sinuses and nasal cavity. J Neurosurg 1998;88:1116-9.

10. Manganaro AM, Ragno JR, Karlis V. Mixed radiolucent/radiopaque lesion of the mandible. J Oral MaxiIlofac Surg 1997; 55:1456-9.

11. Su L, Weathers DR, Waldrom CA. Distinguishing features of focal cemento-osseous dysplasias and cemento-ossifying fibromas. A pathologic spectrum of 316 cases. Oral Surg Oral Med Oral Pathol Oral Radiol Endod 1997; 84:301-9.

12. Lello GE, Sparro OC. Craniofacial poliostotic fibrous displasia. J Oral Maxilofacial Surg 1985;13:267-72.

13. Hammer JE, Scofield HH, Cornyn J. Benign fibro-osseous jaw lesions of periodontal membrane origin: an analysis of 249 cases. Cancer 1968;22:861-8.

14. Regezi JA, Sciubba J. Oral Pathology: Clinical- Pathologic Correlations. $2^{a}$ ed. Philadelphia. WB: Saunders Co, 1993:383.

15. Alandez J, Herrer JI, Sanz M, Carasol M. Mandibular cementifyng fibroma in relation a large periodontal bone defect. Report of a case. J Periodontol 1995;66:291

16. Kramer JRH, Pindborg JJ, Shear H. Histological Ttyping of Odontogenic Tumours. $2^{\mathrm{a}}$ ed. Springer-Verlag, Berlin 1997.

17. Lucas RB. Pathology of Tumours of the Oral Tissues. Edimburg: Livinstone 1984:402-5

18. Martín-Granizo R, Sánchez Cuellar A, Falahat F. Cemento-ossifying fibroma of the upper gingivae. Otolaryngol Head Neck Surg 2000;122:775. in the femur, tibia or phalanx). It causes pain that predominantly occurs during night time which gives good orientation for its differential diagnosis with other bone lesions and it appears as a well circumscribed radiolucent area with sclerotic halo on the X-ray.

Osteoblastoma. It is preferentially in the spine (rarely in the mandible), causes pain and the radiological image varies greatly but is generally poorly defined (in the COF, the lesion is typically well defined) and with erosion of the cortical bone. Benign cementoblastoma. More frequent in those under 20 years of age, generally located in the mandibular molar region and closely associated with dental apices. Pain and expansion of the cortical bone are characteristic symptoms and signs.

Ameloblastic fibroodontoma. Above all, it affects young individuals and the mandibular angle region. A circumscribed lesion surrounded by a sclerotic halo with a radiopaque focus is observed in the radiographic analysis. Histologically, they are lobulated tumors surrounded by a fibrous capsule and formed by mixoid connective tissue with cords of odontogenic epithelium that possess cells still in process of differentiation that produce dentin and enamel.

Cementoblastoma. It appears in the second and third decade of life, more frequently in the posterior mandibular region. It is always associated with dental roots and frequently causes its reabsorption. Radiologically, it is an opaque lesion with a radiolucent halo and the histological study reveals a conglomerate of material similar to cementum and connective tissue. Many of the cemental trabeculae are surrounded by cementoblasts in activity.

Osteomyelitis. The pain, inflammation and involvement of the general condition orients towards an inflammatory condition of this type.

Osteosarcoma. It is a primary malignant bone tumor of rapid progression that causes pain, sensory disorders, limitation of mandibular mobility and displacement or mobility of dental pieces. Rhizolysis and involvement of the cortical bone is frequently observed in the X-ray.

\section{Conclusions}

The COF is a rare entity, with controversial classification that is presently considered to belong to non-odontogenic tumors. It most frequently affects women between 30 and 40 years of age and is basically located in the posterior region of the mandible. It is generally asymptomatic and has a variable radiological appearance, based on evolution time and development phase. It is always a circumscribed lesion and the mixed pattern (in which radiolucent areas alternate with other radiopaque ones) is characteristic of lesions in advanced stages. The histology shows a fibrous connective stroma with trabecular and coalescent calcified spherical foci. Its behavior is benign and local excision of the lesion is sufficient.

\section{Acknowledgements}

To the pathologists, Drs Luis Ortega (Madrid), and Conchita Alvarez-Cañas and Antonio González-Fernández Carreño (Leon) for their help in the histological analysis of the cases. 